\title{
Benign Colorectal Neoplasm
}

National Cancer Institute

\section{Source}

National Cancer Institute. Benign Colorectal Neoplasm. NCI Thesaurus. Code C4610.

A non-metastasizing neoplasm arising from the wall of the colon and rectum. 